Article

\title{
Life Cycle Assessment of Wood Pellet Production in Thailand
}

\author{
Piyarath Saosee ${ }^{1,2,3}$, Boonrod Sajjakulnukit ${ }^{1,2}$ and Shabbir H. Gheewala ${ }^{1,2, *}$ \\ 1 The Joint Graduate School of Energy and Environment (JGSEE), King Mongkut's University of Technology \\ Thonburi, Bangkok 10140, Thailand; piyarath25@gmail.com (P.S.); boonrod.sajjakulnukit@gmail.com (B.S.) \\ 2 Centre of Energy Technology and Environment, PERDO, Ministry of Higher Education, Science, Research \\ and Innovation, Bangkok 10140, Thailand \\ 3 Organization Strategy and Policy Management, National Science and Technology Development \\ Agency (NSTDA), Klong Luang, Pathumthani 12120, Thailand \\ * Correspondence: shabbirg@hotmail.com
}

Received: 8 August 2020; Accepted: 25 August 2020; Published: 27 August 2020

\begin{abstract}
Thailand has increased wood pellet production for export and domestic use. The variations in production processes, raw materials, and transportation related to wood pellet production make it necessary to evaluate the environmental impacts assessment. The objective of this study was to compare via Life Cycle Assessment (LCA), eight different cases of wood pellet production varying in terms of raw materials, production processes, energy use, and the format of transportation and to compare LCA of electricity production from wood pellets and fossil fuels. The comparison results show that leucaena is better as a feedstock for wood pellet production than acacia due to shorter harvest cycle and lesser use of resources. Pellet production consumes the most energy contributing significantly to the environmental impacts. The use of fossil fuels in wood pellet production and transportation also has a major contribution to the environmental impacts. Using wood pellets for electricity production is better than lignite in terms of human health, ecosystem quality and resource scarcity. Recommendations from this study include increasing yield of feedstock plants, shortening harvest cycle, reducing overuse of fertilizers and herbicides, pollution control, reducing fossil fuel use in the supply chain, good logistics, feedstock access, and offering incentives considering the externality cost.
\end{abstract}

Keywords: life cycle assessment; wood pellets; Thailand; para-rubber wood; acacia; leucaena

\section{Introduction}

Woody biomass for energy production has the capability to reduce greenhouse gas (GHG) emissions, as also potentially beneficial economic impacts on rural regions [1,2]. It has been used by humans as the first source of energy. It is still an important source of renewable energy amid energy security concerns. Wood is utilized for fuel in terms of conventional wood (woodchips) and charcoal. At present, technology for low-carbon-driven bio-products using lignocellulosic substrates from agriculture, is still constrained for commercialization due to high cost [3]. Moreover, woody biomass is used for producing torrefied wood pellets (hydrothermal carbonization) and wood pellets (compression). Wood pellets are generally made from compacted sawdust, wood shavings and wood logging residues which is related to biowaste utilization towards a circular economy perspective; biowaste to resource.

Wood pellets are gaining popularity as a biomass-based fuel for heat and electricity production $[4,5]$. Wood pellets are uniform in size and shape, have a high density, and low moisture and ash content. They are easy to store and transport over long distances [6]. The calorific value of wood pellets is 
around 16-18 GJ per tonne [4]. Several countries that aim to reduce fossil fuel use have focused on the increased use of biomass fuels. As a result, global wood pellet production has increased significantly at around 14\% per year since 2011 [4]. The global wood pellet production in 2018 was estimated at 52.7 million tonnes, including wood pellet production in China [7]. The large consumers are UK, Denmark, Benelux countries, Japan, and South Korea; they import the wood pellets from other countries. The US is a major of wood pellet producer and exporter to the European Union [8]. The wood pellet demand of EU has increased, resulting in increased EU production and import [9].

Thailand has the potential to grow plants throughout the year, so biomass feedstock is readily available. Thailand exported 172,441 tonnes of wood pellets in 2019, 70\% to South Korea and 30\% to Japan [10]. Thai entrepreneurs are interested in exporting wood pellets to Japan because it has increased the use of wood pellets for electricity production. Some Thai entrepreneurs share investment with Japanese entrepreneurs. The Kasikorn Research Center has estimated that in 2020, Thailand will export about 80,000-100,000 tonnes of wood pellets to Japan (4.2-5.3\% market share of Japanese import) [10]. The Thai government supports using wood pellets for domestic use only for heat production in industry, not for electricity production. Biomass power plants in Thailand use woodchips or other biomass substitutes (palm shell, paddy and bagasse) for wood pellets because their price is cheaper [11].

The Thai government intends to reduce emission of greenhouse gases; this is reflected in several policies, a major one being the promotion of biomass-based energy [12]. The target of biomass use in the Alternative Energy Development Plan (AEDP2015) of Thailand has been set to produce $5570 \mathrm{MW}$ of renewable energy. However, the Thai government promotes the use of wood pellets only for heat production in industry; they have initiated to support $30 \%$ to $50 \%$ of the cost to adjust factory boilers to allow for the use of wood pellets [13]. The main raw material for wood pellet factories in South Thailand is from para-rubber trees which are cut at the age of 25 years when the yield of latex is reduced. The Rubber Authority of Thailand supports cutting 64,000 hectares of para-rubber trees every year to raise the price of latex. Hence, Thailand has about 8 million tonnes per year (dry weight) of waste wood from para-rubber trees [10]. Furthermore, several studies presented that the fast-growing tree cultivation should be encouraged in wasteland (areas unsuitable for agriculture, without irrigation systems, not for housing, not conservation area and not government areas) [14]. Leucaena and acacia are the suggested fast growing trees for raw material of biomass fuel $[15,16]$. Thai entrepreneurs have been persuading farmers to grow these trees on contract farming for renewable energy.

From the above data, it can be concluded that opportunities of wood pellet production in Thailand are enough from the point of feedstock from para-rubber waste wood, wood pellet consumption for reducing greenhouse gas emissions, and supporting the Thai government to use wood pellets for domestic use, including also the increase of export demand. Moreover, the wood from fast growing trees grown and expanded in the wasteland of Thailand can be another important source of raw materials. Although the wood pellets are used widely in several countries, wood pellet production and consumption in Thailand has recently expanded, highlighting the increased wood pellet export. The wood pellet factories increased in the last two years, especially in the south of Thailand which is full of resources. However, the high cost of wood pellet production in Thailand is one of the barriers for export, and lack of incentives for entrepreneurs to use wood pellets in the industry is another obstacle for supporting domestic use.

The wood pellets are used to substitute fossil fuels to reduce environmental impacts [17]. However, there has not yet been a systematic study in Thailand about the environmental impacts of wood pellets considering the entire life cycle. At present, importers request a certificate of forestry management for raw material cultivation to ensure that it is not sourced from deforestation. Therefore, sustainable wood pellet production is a national challenge, regardless of whether they are used locally or internationally. Thus, the study on Life Cycle Assessment (LCA) of wood pellet production in Thailand is necessary and important to present the status of the environmental impacts and then plan for reduction of these impacts to ensure clean energy in the future. 
LCA is an appropriate tool for evaluating the environmental impacts of wood pellet production as it has been widely used for product development, product improvement, strategic planning, public policy making, and marketing and communication [18]. It quantifies the input resources and emissions to the environment throughout the life cycle of a product, from raw material production to processing, use, and disposal [19]. Several LCA studies of wood pellet production have indicated that the environmental impacts of wood pellet production are related to energy use from electricity and fossil fuels [20,21]. In a review of 19 sources with 48 case scenarios, Muazu et al. (2017) emphasized that fuel use during transport was a large contributor to the environmental burdens of the wood pellet production [22]. The LCA studies, which included cultivation of wood, showed that chemical fertilizers and pesticides contributed significantly to the environmental impacts [23,24]. Apart from transportation, pelleting and drying stages were also indicated as environmental hotspots in other studies [25]. Moreover, LCA used to compare the environmental impacts of using wood pellets, fossil fuels, wood, and torrefied wood pellets for electricity production showed that wood pellets had lower impacts than fossil fuels for global impact categories [26-28], but they were worse on local impact categories such as particulate matter formation, human toxicity, photochemical ozone formation, freshwater eutrophication, and land use [24,27]. The environmental burdens of wood pellets were higher the torrefied pellets, the relative impact improvement depending on the biomass drying requirement and the proportion of total process heat supplied [29].

Thus, this study uses LCA to evaluate the environmental impacts associated with wood pellets in Thailand. The objective of this study is to compare the environmental impacts of eight cases of wood pellet production which differ in terms of raw materials, production processes, energy use, and the transportation distance, and to compare the environmental impacts of electricity production from wood pellets and fossil fuels. Although wood pellets are known as a renewable energy that reduce the impact of climate change, other impacts have not received much attention in the literature. This study thus considers a full life cycle assessment including 17 midpoint and 3 endpoint impact categories and the contribution of each phase of the wood pellet life cycle (cradle to gate). The outcomes can be used to select suitable case for raw materials, and to adjust production processes and logistics, leading to comprehension of the barriers and opportunities, and reduction of the environmental impacts for sustainable wood pellet production. Even though this study is based on Thailand, the findings and insights of this study will supply a new reference to future improvement of wood pellet production from other types of wood in regions with similar climate and production conditions. Moreover, the findings and insights of this study can be used to develop the processes and logistics of wood pellet production for other regions as well.

\section{Materials and Methods}

LCA in this study is calculated by SimaPro software (version 8.5.2.0) and the ReCiPe2016 Midpoint/Endpoint method (version 1.02) is used for the impact assessment [30]. This study includes the following 17 midpoint impact categories: global warming potential, stratospheric ozone depletion, ozone formation (human health), ozone formation (terrestrial ecosystems), fine particulate matter formation, terrestrial acidification, freshwater eutrophication, marine eutrophication, terrestrial ecotoxicity, freshwater ecotoxicity, marine ecotoxicity, human carcinogenic toxicity, human non-carcinogenic toxicity, land use, mineral resource scarcity, fossil resource scarcity, and water consumption. The endpoint categories are resources scarcity, ecosystem quality, and human health.

\subsection{Description of the Case Studies}

The study comprises eight cases of wood pellet production which are different in terms of the type of raw materials, production processes, energy use and the format of transportation (see Table 1). Each case is chosen to represent a different wood pellet production model with varying energy carriers, chemicals use, and wood pellet feedstock characteristics. The scenarios cover the characteristic of factories in the various regions of Thailand which utilize different raw materials, including use of fast 
growing tree (acacia and leucaena), para-rubber wood, and waste wood, and different production processes. Cases A, B, C, and D are the expected cases if the government will support the projects on planting fast growing trees (leucaena and acacia). Cases $\mathrm{E}$ to $\mathrm{H}$ use para-rubber wood which is abundantly grown in the southern region. The para-rubber wood pellets production tends to increase with demand from export; Case E could occur if the wood pellet demand surges leading to intense competition for the acquisition of para-rubber wood between the wood pellet factory and furniture industry. Normally, the para-rubber wood is processed to para-rubber jointed board and plywood. If the demand of para-rubber wood pellets is high until the factories use trunk and branch of para-rubber wood (not waste wood), it is interesting to know what the environmental impacts will be. Cases F, G, and H represent actual cases. Case F used para-rubber waste wood (70\% of fresh sawdust and $30 \%$ of barks) which can normally be found in the South region. Case G used dried sawdust (moisture content 10-30\%) which seems to be the best raw material for wood pellet production as it does not require a drying process. The dried sawdust of Case $\mathrm{G}$ is waste wood from the furniture industry which is contaminate with chemicals from para-rubber wood processing. Hence, it is important to know the effects from Case G compared to the wood pellet production in other cases. Finally, Case $\mathrm{H}$ presents the long distance of transportation.

Table 1. Details for eight cases of wood pellet production in Thailand.

\begin{tabular}{ccccc}
\hline Case & Type of Feedstock & Characteristics of Raw Material & Factories & Transportation * \\
\hline A & Leucaena wood & Trunk and branch & F1 & T1 \\
B & Leucaena wood & Trunk and branch & F2 & T1 \\
C & Acacia wood & Trunk and branch & F1 & T1 \\
D & Acacia wood & Trunk and branch & F2 & T1 \\
E & Para-rubber wood & Trunk and branch & F2 & T1 \\
F & Para-rubber waste wood & 70\% Fresh sawdust + 30\% Bark & F2 & T2 + T3 \\
G & Para-rubber waste wood & Dried sawdust (MC 10-13\%) & F3 & T2 + T3 \\
H & Para-rubber waste wood & Fresh sawdust & F4 & T2 + T4 \\
\hline
\end{tabular}

* Transportation by 10 wheel truck, fuel: diesel. T1: Transportation from the wood pellet factory to the planting area $(0 \%$ loading) and the return trip $(100 \%$ loading), distance from the wood pellet factory to the planting area: $100 \mathrm{~km}$. T2: Transportation from the para-rubber wood processing factory to the planting area ( $0 \%$ loading) and the return trip (100\% loading), distance from the para-rubber wood processing factory to the planting area: $100 \mathrm{~km}$. T3: Transportation from the para-rubber wood processing factory to the wood pellet factory ( $80 \%$ loading), distance from the para-rubber wood processing factory to the wood pellet factory: $100 \mathrm{~km}$. T4: Transportation from the para-rubber wood processing factory to the wood pellet factory ( $80 \%$ loading), distance from para-rubber wood processing factory to the wood pellet factory: $1000 \mathrm{~km}$.

The factories F1, F2, F3, and F4 show differences in processes, energy use and the distance of transportation. The main equipment and machines used in factories F1 to F4 are shown in Table 2. The Factory F1 is based in the north of Thailand. Their raw material is general wood available around the factory. The raw material of F1 has a rather high moisture content $(>25 \%)$; thus, F1 has two rotary drum dryers to decrease the moisture content of wood. Hence, F1 has the most energy consumption. Moreover, F1 has less area for stocking raw materials. F2 and F3 are set in the south of Thailand. Main raw material for them is para-rubber waste wood widely available in the south of Thailand. F2 is the normal factory; it includes pre-treatment, drying, comminution, pelletization, cooling, and storage. F3 uses dry sawdust (moisture content 10-13\%) from the para-rubber wood processing factory, so it does not need an additional drying process. F4 is based in central Thailand but uses fresh sawdust from the south of Thailand. 
Table 2. Equipment and machines of Factories F1-F4.

\begin{tabular}{ccccc}
\hline Equipment/Machines (Unit) & F1 & F2 & F3 & F4 \\
\hline Chopper & 1 & 1 & 0 & 0 \\
Hammer mill & 1 & 1 & 1 & 0 \\
Screener & 1 & 1 & 1 & 1 \\
Rotary drum dryer & 2 & 1 & 0 & 1 \\
Pellet mill & 2 & 3 & 2 & 4 \\
Cyclone & 1 & 1 & 1 & 1 \\
Cooler & 1 & 1 & 1 & 1 \\
\hline
\end{tabular}

\subsection{LCA of Wood Pellet Production from Different Scenarios}

\subsubsection{Functional Unit and System Boundary}

The functional unit is the production of one tonne of wood pellets. The entrepreneurs can consider the results of this study to choose or manage suitable raw materials, production processes and the best logistics. In addition, these results can be applied by the Thai government for policy decisions. The system boundary of Cases A, B, C, D, and E, (Figure 1, dashed line) consists of three main parts: industrial forest plantations, transportation, and wood pellet production. The sprout of para-rubber tree, leucaena or acacia is prepared in the first step of industrial forest plantations. The next steps are cultivation, maintenance, and cutting which differ according to the type of plant. Para-rubber trees are grown and maintained for seven years; from the eighth year onwards, they can yield some latex which is the main product. The chemical fertilizers and herbicides are applied in the farm every year. The yield of latex reduces when their age is over 25 years. In the past, the para-rubber trees were cut to use for the furniture industry. Presently, para-rubber wood and waste wood are used for renewable energy production.

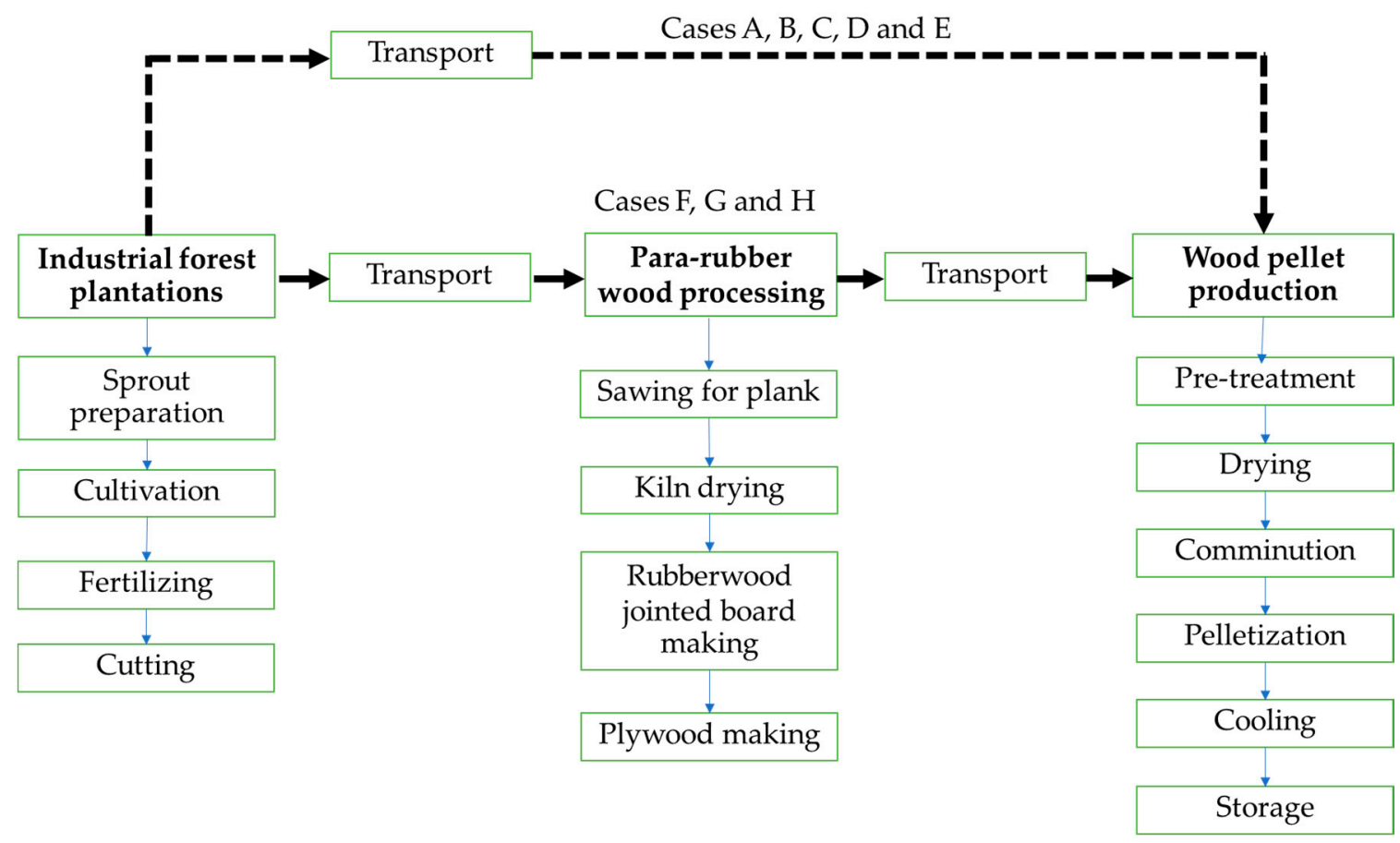

Figure 1. System boundary for the cradle to gate life cycle assessment of wood pellet production:

Dashed line for Cases A, B, C, D, and E; Solid line for Cases E, F, G, and H.

For leucaena, about $85 \%$ of the tree is partially harvested (leaving about one meter of the trunk above the ground to regenerate) every year for ten years (ten years per one crop), while for acacia, 
the entire tree will be cut off after growing for five years (five years per one crop). The wood in terms of trunk and branch is sent to the wood pellet factory. The wood pellet production processes of each factory are different. The system boundary of Cases F, G, and H (Figure 1, Solid line) consists of four main parts, it has an additional unit process of para-rubber wood processing. Raw material for Case $\mathrm{F}$ is $70 \%$ of fresh sawdust and $30 \%$ of bark which are generated at the plank sawing process. Factory F3 of Case G uses only dried sawdust, so a drying process is not required in wood pellet production. Dried sawdust of F3 can be collected from rubberwood jointed board making and plywood making processes. For Cases E, F, G, and H which used the para-rubber tree for wood pellets production, economic allocation was chosen to divide the environmental burdens between the two co-products: latex and wood. As latex is the main product, it shared $69 \%$ of the environmental burdens from cultivation due to its higher price (see in Appendix A). The fresh para-rubber wood shared the remaining $31 \%$ of the environmental burdens. The shares of the environmental burdens of bark, fresh sawdust, and dry sawdust are shown in Appendix A.

\subsubsection{Inventory Analysis}

The objective of the Life Cycle Inventory (LCI) is to identify and quantify the energy, water, and materials flows. Data were collected from several sources to evaluate the environmental impacts. The sources of data were field surveys, scientific reports and LCI databases (ecoinvent 3, the Thai National LCI database and the U.S. Life Cycle Inventory database). The ecoinvent and U.S. Life Cycle Inventory databases were adapted to Thai conditions. The mass balance and the material flow of each process were calculated between each process and across the system boundary, relating to the functional unit. The energy use (fuel and electricity) of each process of the system was measured, including information on energy sources. Finally, the emissions from the system boundary were calculated for each process, especially the combustion process for drying.

Para-Rubber Wood Plantation and Cutting

Para-rubber tree (Hevea brasiliensis) is the most economically important tree because milky latex from the para-rubber tree is a source of natural rubber. Latex production decreases when the para-rubber tree reaches the age of 25 to 30 years, so the old para-rubber trees are cut down and replanted. The para-rubber wood is used in the furniture production. At present, the para-rubber wood is one type of raw material in wood pellet production to generate energy. Five types of materials from para-rubber wood are used for wood pellet production including fresh sawdust, dry sawdust, bark, trunks, and branches. Use of each para-rubber wood component depends on the factory (see Table 1). The LCI data of para-rubber sprout preparation, plantation and cutting were collected from a project on the water footprint of para-rubber cultivation in new areas in the south of Thailand as presented in Appendix B. These data focus on 8000 hectares of para-rubber plantation areas in 12 provinces in southern Thailand (Chumphon, Ranong, Phangnga, Phuket, Krabi, Trang, Nakhonsithammarat, Pattalung, Satun, Pattani, Yala, and Narathiwat) [31]. The LCI data of para-rubber wood processing were referred from a project on the life cycle assessment and eco-efficiency of para-rubber production in Thailand, presented in Appendix B. The data were collected from six factories in southern Thailand [32].

\section{Fast-Growing Tree Plantation and Cutting}

Nowadays, several entrepreneurs use fast growing trees for feedstock production of wood pellets. Leucaena leucocephala and Acacia spp. are popular fast growing trees of Thailand. Leucaena can grow very well in Thailand; it is considered for biomass production because of its high yield [33]. Acacia has a large genus; Acacia auriculiformis Cunn and Acacia mangium are popularly grown in the general areas in Thailand. Leucaena and acacia sprout plantation data were surveyed from a farm in Uthaithani province. Leucaena and acacia plantation data were referred from the project, "Greenhouse gas inventory development for fast-growing trees used as biomass fuel in Thailand". In this study, leucaena was harvested every year for 10 years; only $85 \%$ of the tree was cut each year, the remaining $15 \%$ left to 
regenerate. As the entire acacia plant will be harvested at the age of 5 years, the farmers will replant every 5 years. However, the farmers prefer the leucaena tree to acacia because they can cut the leucaena tree every year. LCI of leucaena and acacia industrial forest plantations is presented in Appendix C.

\section{Wood Pellet Production}

The normal wood pellet production process comprises six processes: pretreatment, drying, comminution, pelletization, cooling, and storage. Firstly, pretreatment is carried out to recheck and sort soil, stones, and metals from the raw material, including downsizing of raw material in case of trunk or branch. Secondly, drying of the raw material by a rotary drum dryer reduces the moisture content from about $30-40 \%$ to about $10 \%$. Thirdly, the raw material is ground in a hammer mill and wood flour is separated in a cyclone. Fourthly, pelletizing, a compression process, is carried out with a rolling press through a die block. Fifthly, cooling is required because it increases the durability of the wood pellets and decreases the formation of dust during transportation and handling. The cooling process uses a counter flow cooler to reduce the temperature from $70-80^{\circ} \mathrm{C}$ to $30-40{ }^{\circ} \mathrm{C}$ after which the pellets are loaded in big bags. LCI of wood pellet production from the four factories is shown in Table 3. Air emissions from combustion use the data from the U.S. Life Cycle Inventory Database as shown in Appendix D. According to a survey of wood pellets factories, three types of energy were used: diesel (for vehicles in a factory such as forklift trucks and tractors), firewood (used in the furnaces for heat production in the drying process), and electricity (used in various equipment and machineries). The use of diesel and firewood was collected from factory records. Electricity consumption was measured during wood pellet production throughout a batch of production by using a power meter to measure the electricity consumption in each machine from the main distribution board. The results were summarized and rechecked with the results from the main electric meter.

Table 3. Life cycle inventory data for wood pellet production of the factories F1-F4.

\begin{tabular}{cccccc}
\hline Process/Activity & Unit & F1 & F2 & F3 & F4 \\
\hline Wood Pellet Production per Batch & & & & & \\
$\quad$ Input & & & & & \\
Raw material & tonne & 1.60 & 1.25 & 1.01 & 1.50 \\
Electricity & $\mathrm{kWh}$ & 150 & 87 & 112 & 120 \\
$\quad$ Diesel & $\mathrm{L}$ & 2.0 & 0.4 & 0.3 & 0.5 \\
Firewood (bark) & tonne & 0.17 & 0.06 & 0 & 0.20 \\
$\quad$ Output & & & & & \\
Wood pellet & tonne & 1.0 & 1.0 & 1.0 & 1.0 \\
\hline
\end{tabular}

Source: primary data collected from four factories in Thailand.

\section{Transportation}

Transportation for Cases A, B, C, D, and E, starting from wood pellet factory to a farm is $100 \mathrm{~km}$ by 10 -wheel truck, with 16 tonnes of rubber wood log (100\% loading) $0 \%$ loading on the return trip. Cases $\mathrm{F}$ and $\mathrm{G}$ have two steps of transportation, 1st step starts from the para-rubber wood processing factory to a farm and the return trip, and 2nd step starts from the para-rubber wood processing factory to the wood pellet factory and the return trip. The transport conditions of the two steps for Cases $\mathrm{F}$ and $\mathrm{G}$ are the same as for Cases A, B, C, D, and E. Transportation of Case H also has two steps like Cases $\mathrm{F}$ and $\mathrm{G}$, but the distance of the Factory F4 from the para-rubber wood processing factory is about $1000 \mathrm{~km}$.

\subsection{LCA of Electricity Production from Wood Pellets}

\subsubsection{Functional Unit and System Boundary}

The functional unit of comparing LCA for electricity production from acacia, leucaena and para-rubber wood pellets (Cases B, D, and F in Table 1), lignite and natural gas is one kWh of electricity 
production. Cases B, D, and F are chosen as representatives of the normal case for wood pellet production in Thailand. The selected fossil fuels are lignite and natural gas; these are the ones normally used for electricity production in Thailand. The system boundary covers cultivation, wood pellet production, electricity production, and transportation.

\subsubsection{Inventory Analysis}

LCI of cultivation and wood pellet production can be seen in the previous sections. LCI of electricity from conversion of woodchips and barks to wood pellets is shown in Table 4. At present, the biomass power plants in Thailand hardly use wood pellets for electricity production as the price of wood pellets is higher than woodchips and bark. These data were collected from a 9.9 MW power plant in the south of Thailand. They used the barks of para-rubber tree as the basic raw material. A lot of para-rubber bark is available from the processing of para-rubber wood factories. If the bark of para-rubber tree is not available, then woodchips are used instead. Air emissions from the combustion of wood pellets have been referred from Appendix E.

Table 4. Life Cycle Inventory (LCI) of electricity from the wood pellets.

\begin{tabular}{ccc}
\hline Input & Units & Amount \\
\hline Wood pellets $^{1}$ & $\mathrm{~kg}$ & $7.98 \times 10^{-1}$ \\
Diesel & $\mathrm{L}$ & $7.56 \times 10^{-4}$ \\
Electricity & $\mathrm{kWh}$ & $5.42 \times 10^{-4}$ \\
Output & $\mathrm{kWh}$ & 1
\end{tabular}

Note $^{1}$. Converted from woodchips/barks (Heating value of woodchips is $8 \mathrm{MJ}$ per $\mathrm{kg}$ ). Heating value of wood pellets is $16 \mathrm{MJ}$ per $\mathrm{kg}$.

\section{Results and Discussion}

\subsection{Endpoint Environmental Impacts for One Tonne of Wood Pellet Production}

The result of comparison of the endpoint impacts of one tonne wood pellet production from each case (Figure 2) shows that Cases $C$ and D are higher than Cases A and B in human health and ecosystem quality impacts. This was mainly because acacia (Cases $C$ and $D$ ) consumes about double the resources as leucaena (Cases A and B) due to different harvesting cycles. One crop of acacia which is cut at five years age, results in it being grown twice when compared with leucaena, which is harvested every year for a ten year cycle. The endpoint impacts of Case $A$ are higher than Case B, and Case $C$ higher than Case D, even though raw material for Cases A and B or Cases C and D is same. These results indicate that high energy use of the Factory F1 effect on endpoint impacts absolutely.
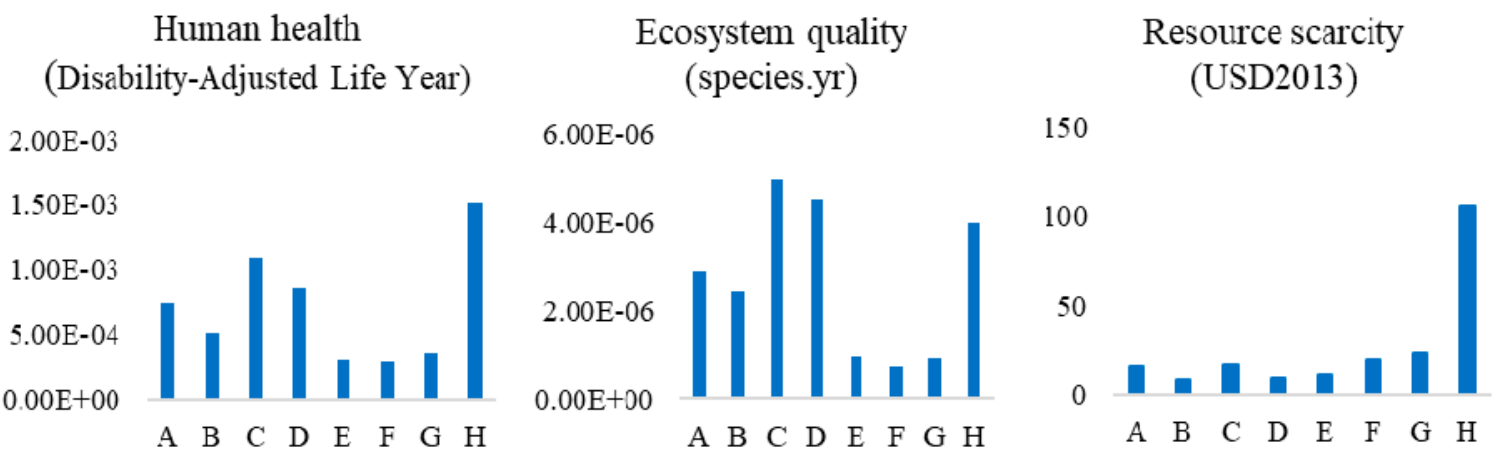

Figure 2. Comparative endpoint analysis for the eight cases of wood pellet production. 
Human health and ecosystem quality impacts of Cases E, F, and G, which used the para-rubber tree, are better than both leucaena (Cases $A$ and $B$ ) and acacia (Cases $C$ and D). The yield of para-rubber tree is 285 tonnes per hectare per 25 years or 11.4 tonnes per hectare per year (yield of leucaena and acacia are 19 and 17 tonnes per ha per year, respectively). It must also be noted that the para-rubber tree produces latex shares the major part of the environmental impacts due to its much higher economic value as compared to the wood. Resource scarcity impact of Case $\mathrm{H}$ is the highest of all (except in ecosystem quality impact) because of the diesel used in vehicles for long distance transport to collect raw materials, $1000 \mathrm{~km}$ from the factory.

The Case G (dried sawdust) is higher than Cases $\mathrm{E}$ and $\mathrm{F}$ in human health and resource scarcity impacts although Case G (the Factory F3) does not have drying process (emissions to air). This is because dried sawdust of the para-rubber tree used in Case G can be loaded only at $80 \%$ of the capacity weight reducing the efficiency of transportation; this obviously affects the increase in environmental impacts. This result has values similar to those reported by Muazu et al. [26] in are view of biomass densification systems studies. Case F is the lowest in human health and ecosystem quality impacts; it is the Factory F2 using waste of para-rubber tree (fresh sawdust and bark) and two trips of transportation. The waste of para-rubber tree in Case F shares only $3 \%$ of the total environmental impacts of cultivation. However, global warming potential, ozone formation and fossil resource scarcity of Cases F and G present high impacts due to only $80 \%$ loading of sawdust. Transportation of sawdust has low efficiency (see detail in Figure 3).

The result of human health and ecosystem quality impacts for Case $\mathrm{E}$ is similar to Case $\mathrm{F}$ (the Factory F2); but it uses main of the para-rubber tree (trunks and branches) and one cycle of transportation. However, as will be seen in Section 3.2, the midpoint environmental impacts for some impact categories of Case E are higher than other cases. Resource scarcity impact of Cases F and G is higher than Case E owing to higher energy use for two trips in transportation. If the entrepreneurs can set the wood pellet factory (Case F) in the vicinity of the para-rubber wood processing factory, the environmental impacts will be decreased.

\subsection{Midpoint Environmental Impacts for One Tonne of Wood Pellet Production}

The results of comparing the midpoint environmental impacts for one tonne of wood pellet production for each case are shown in Figures 3 and 4. The trend of comparing the midpoint impacts results in global warming, ozone formation, fine particulate matter formation, terrestrial acidification, terrestrial ecotoxicity, marine ecotoxicity and fossil resource scarcity are identical. The energy consumption of wood pellet production affects these environmental impacts, so Case B is better than Case A, and Case D is better than Case C. Global warming, human carcinogenic toxicity, marine ecotoxicity, and fossil resource scarcity of Case G are rather high, next to Case H. This is mainly caused by use of diesel in transportation, and electricity in wood processing and wood pellet production, which is similar to trends found in other studies [20,21].

Water consumption of acacia (Cases C and D) is higher than leucaena because of two crops of acacia cultivation in ten years (compared with one crop of leucaena). Stratospheric ozone depletion, freshwater eutrophication, marine water eutrophication, land use and freshwater ecotoxicity of Case $\mathrm{E}$ are highest because it directly uses the para-rubber wood whereas Cases F, G, and $\mathrm{H}$ use para-rubber waste wood (sawdust and bark). The environmental burdens of Cases F, G, and H are rather low due to sharing with main products of wood. Hence, using para-rubber waste wood for wood pellet production is more suitable than using para-rubber wood. This finding is consistent with other studies that also reveal that the use of residues is better than standing trees for environmental issues [34].

The contribution of the life cycle stages is similar for Cases A and C which consider wood pellets produced by the Factory F1 (Figure 5). The contribution of wood pellet production in Cases A and $\mathrm{C}$ are more than $50 \%$ in 13 environmental impact categories. These results are related to the energy consumption of the Factory F1 at 610 MJ per tonne of wood pellets. Likewise, the contribution of the life cycle stages is similar for Cases B and D which consider wood pellets produced by the factory F2. 
The energy consumption of the Factory F2 is only $46 \mathrm{MJ}$ per tonne of wood pellets. Therefore, the most contributions in Cases B and D are from transportation which shares more than $50 \%$ in seven impact categories, and cultivation which shares more than $50 \%$ in three impact categories.

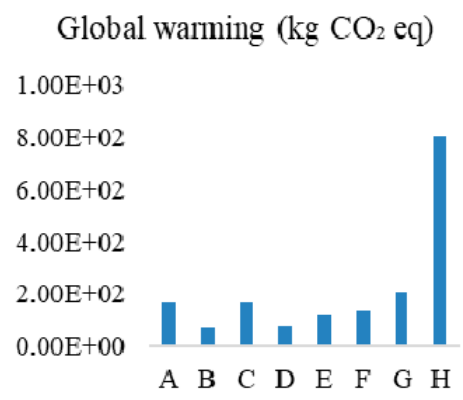

Ozone formation, Human health (kg NOx eq)

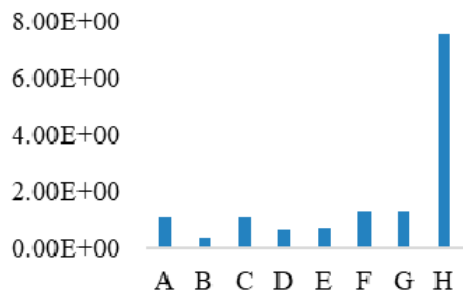

Freshwater eutrophication (kg P eq)

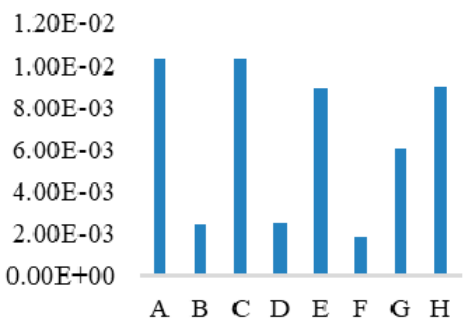

Mineral resource scarcity (kg Cu eq)

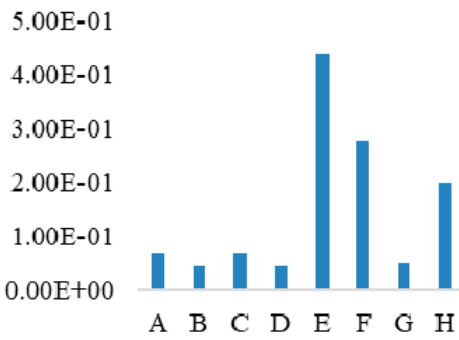

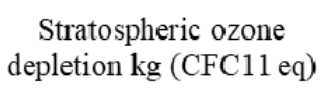

$1.50 \mathrm{E}-03$

$1.00 \mathrm{E}-03$

$5.00 \mathrm{E}-04$

$0.00 \mathrm{E}+00$

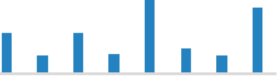

A B C D E F G H

Ozone formation, Terrestrial ecosystems (kg NOx eq)

$8.00 \mathrm{E}+00$

$6.00 \mathrm{E}+00$

$4.00 \mathrm{E}+00$

$2.00 \mathrm{E}+00$

$0.00 \mathrm{E}+00$

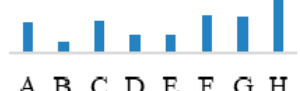

Marine eutrophication ( $\mathrm{kg} \mathrm{N} \mathrm{eq)}$

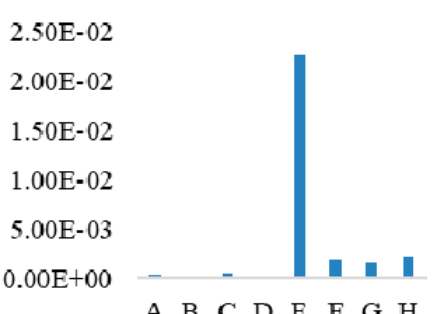

Fossil resource scarcity ( $\mathrm{kg}$ oil eq)

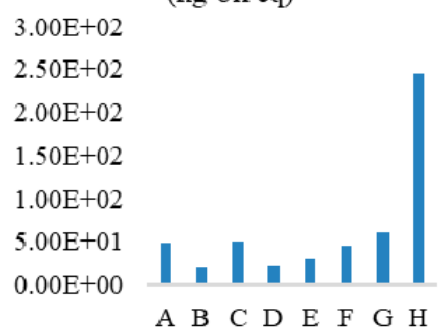

Fine particulate matter formation (kg PM2.5 eq) $1.50 \mathrm{E}+00$

$1.00 \mathrm{E}+00$

$5.00 \mathrm{E}-01$

$0.00 \mathrm{E}+00$

Terrestrial acidification $\left(\mathrm{kg} \mathrm{SO}_{2}\right.$ eq)

$3.00 \mathrm{E}+00$

$2.00 \mathrm{E}+00$

$1.00 \mathrm{E}+00$

$0.00 \mathrm{E}+00$

A B C D E F G H

Water consumption $\left(\mathrm{m}^{3}\right)$

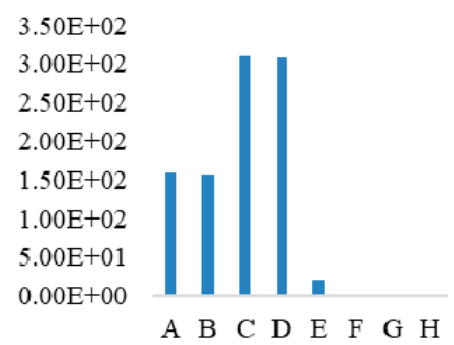

Land use $\mathrm{m}^{2} \mathrm{a}$ crop eq

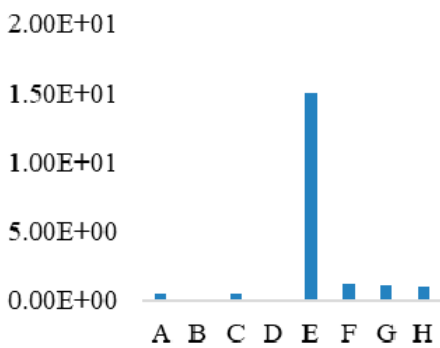

Figure 3. The midpoint environmental impacts for the eight cases of wood pellet production.

Remarkably, the environmental impacts of the Case H spiked in 11 impact categories except for stratospheric ozone depletion, freshwater eutrophication, marine eutrophication, land use, mineral resource scarcity, and water consumption which are lower. Contribution of para-rubber tree wood pellets life cycle phases of Case H (Figure 6) indicates that the environmental impacts from transportation are over $70 \%$ in all impacts except freshwater eutrophication, marine eutrophication, human non-carcinogenic toxicity, land use, mineral resource scarcity and water consumption. Although transportation of raw material for Case $\mathrm{H}$ is about $1000 \mathrm{~km}$ from the Factory F4, the wood pellets are sent to users nearby ( $10 \mathrm{~km}$ from Factory F4). Even though cost of production and transportation can 
be controlled, this case shows the highest environmental impacts. Hence, the externality cost should be considered for the future wood pellet production. Despite low endpoint environmental impacts for Case E, stratospheric ozone depletion, marine eutrophication, land use, and mineral resource scarcity of Case E are the highest when compared with other cases. Stratospheric ozone depletion, marine eutrophication, and mineral resource scarcity are associated with use of chemical fertilizers $\left(\mathrm{N}, \mathrm{K}_{2} \mathrm{O}\right.$, and $\left.\mathrm{P}_{2} \mathrm{O}_{5}\right)$. This result is in accordance with the other LCA studies which also show that chemical fertilizers and pesticides contributed substantially to the life cycle environmental impacts [22,23].

Terrestrial ecotoxicity (kg 1,4-DCB)

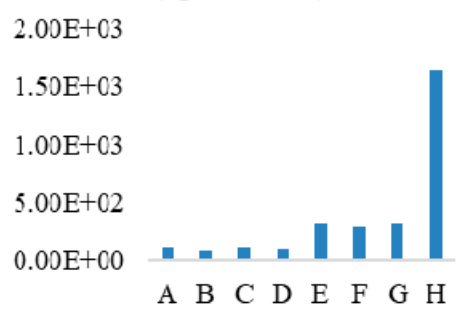

Human carcinogenic toxicity (kg 1,4-DCB)

$2.00 \mathrm{E}+00$

$1.50 \mathrm{E}+00$

$1.00 \mathrm{~F}+00$

5.00E-01

$0.00 \mathrm{E}+00$

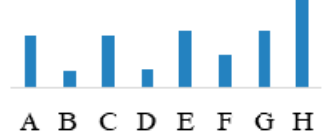

Freshwater ecotoxicity (kg 1,4-DCB)

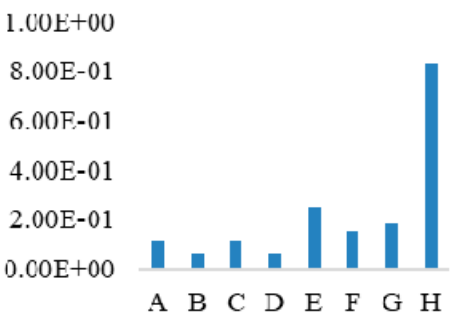

Human non-carcinogenic $3.00 \mathrm{E}+02$ toxicity ( $\mathrm{kg} \mathrm{1,4-DCB)}$

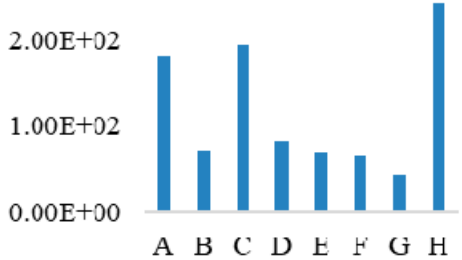

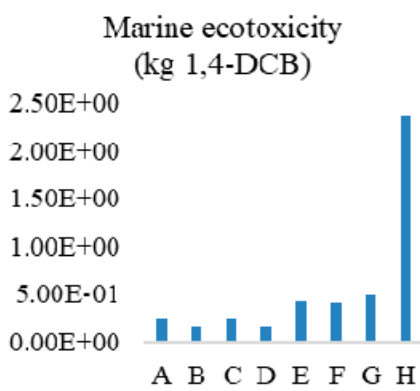

A B C D E F G H

Figure 4. The midpoint environmental impacts (toxicity) for the eight cases of wood pellet production.

Case $\mathrm{E}$ uses the trunk of para-rubber tree as raw material which shared $31 \%$ of the environmental impacts. The contribution of para-rubber tree cultivation and cutting (Figure 4 ) is more than $50 \%$ in all impact categories except ozone formation and human non-carcinogenic toxicity. The para-rubber tree plantation and cutting of Case E contributes $85 \%$ of the freshwater eutrophication, which is mainly related to the use of chemical fertilizer (Figure 4). Meanwhile, freshwater eutrophication of Cases F, G, and H can be caused by electricity use and wood ash (from the combustion of drying process). Electricity production in Thailand uses natural gas, coal, and biomass for fuel. LCA of electricity production from these three fuels, especially coal, is directly related to freshwater eutrophication [35-37]. Furthermore, the wood ash is a major contributor to human non-carcinogenic toxicity. The high value of marine eutrophication in Cases E, H, F, and G is mainly due to chemical fertilizer and diesel for transportation which releases NOx from fossil fuels burning. After that, NOx is redeposited to land and water through a wet deposition [38]. However, Proto et al. reported increase of the environmental impacts from woody production related to fuel combustion from diesel engines and vehicles in felling, processing, and logging operations. The main impact categories were photochemical ozone formation, climate change, human toxicity, non-cancer, terrestrial eutrophication, freshwater eutrophication [39]. Meanwhile, the combustion of woody biomass also causes environmental impacts, especially particulate matter formation [40]. Therefore, although wood pellets are considered as clean energy, pollution control should nevertheless be considered for the production and use of wood pellets both from the use of fossil fuels and wood pellets combustion.

In case of land use, the Intergovernmental Panel on Climate Change (IPCC) reported that there could be significant benefits to land-based carbon removal from afforestation and reforestation, bioenergy with carbon capture and storage (BECCS), soil carbon and biochar [41]. Carbon stock of para-rubber plantation is 50-200 tonne $C$ per ha [42]. Para-rubber trees with age more than 20 years 
have above-ground biomass carbon at 91.5 tonne $C$ per ha and topsoil $(0-30 \mathrm{~cm}) 34.2$ tonne $C$ per ha [43]. Arjharn et al. evaluated that the carbon stock of leucaena and acacia (year: 1st-5th) are 46-1980 tonne $C$ per ha and 173-4575 tonne $C$ per ha, respectively [44]. Therefore, para-rubber and fast growing tree plantations are a source to absorb carbon dioxide from the atmosphere and serve as important carbon storage areas which is related to sustainable land management (to prevent and reduce land degradation, maintain land productivity), including to reverse the adverse impacts of climate change on land degradation [41]. Moreover, using of wood pellets for energy production can be the starting point of BECCS.
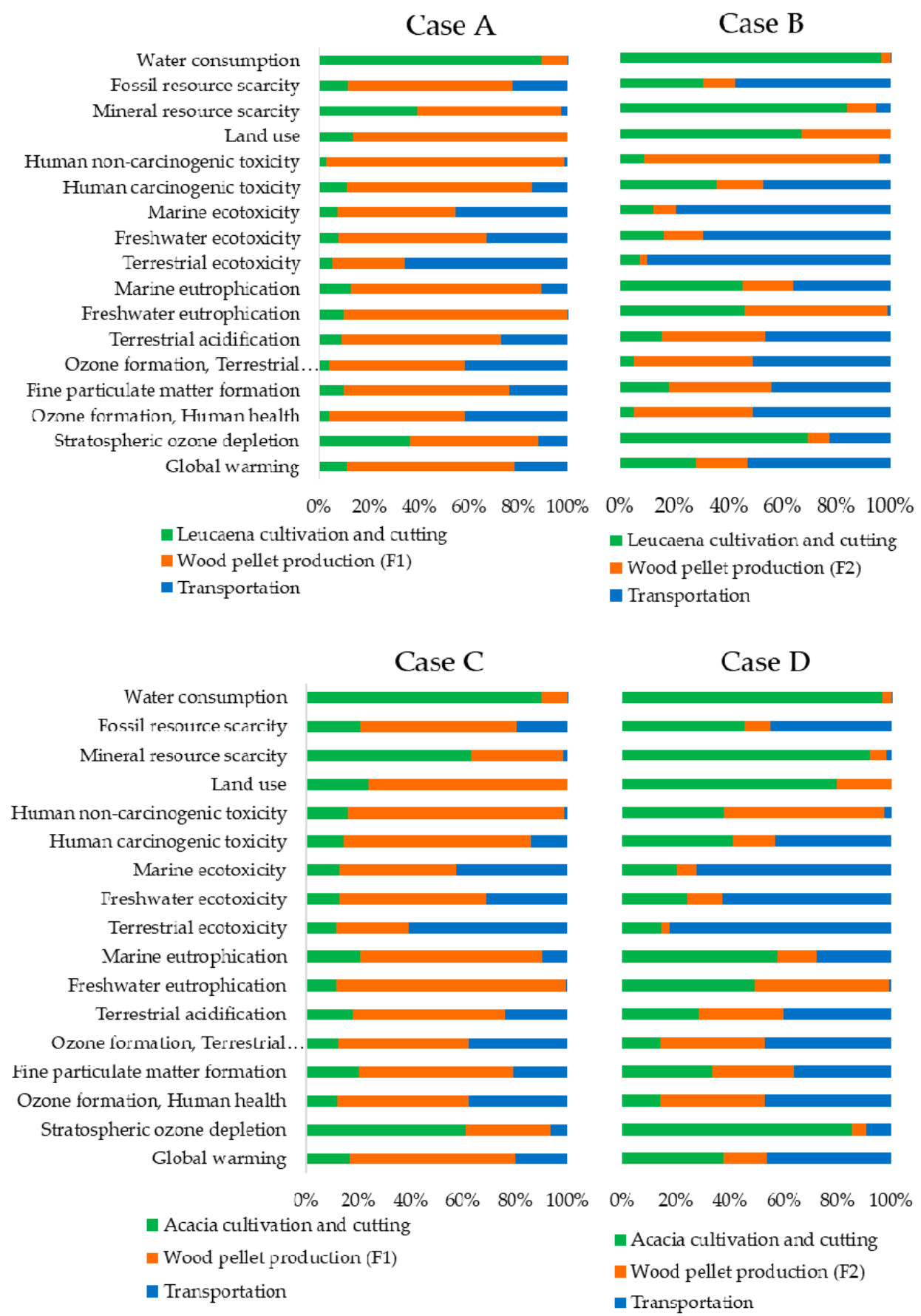

Figure 5. Contribution of fast-growing tree wood pellets life cycle phases to the midpoint impact categories (Cases A-D). 


\section{Case E}

Water consumption

Fossil resource scarcity

Mineral resource scarcity

Land use

Human non-carcinogenic.

Human carcinogenic toxicity

Marine ecotoxicity

Freshwater ecotoxicity

Terrestrial ecotoxicity

Marine eutrophication

Freshwater eutrophication

Terrestrial acidification

Ozone formation, Terrestrial.

Fine particulate matter.

Ozone formation, Human.

Stratospheric ozone depletion

Global warming

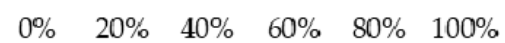

- Para-rubber cultivation and cutting

- Wood pellet production (F2)

- Transportation

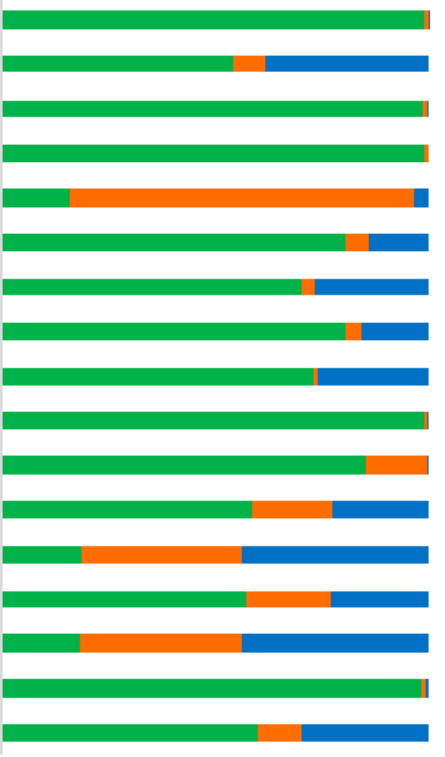

ons

\section{Dara-rubber cultivation, cutting and processing - Wood pellet production (F2)}

\section{Case G}

Water consumption

Fossil resource scarcity Mineral resource scarcity Land use

Human non-carcinogenic.. Human carcinogenic toxicity Marine ecotoxicity

Freshwater ecotoxicity

Terrestrial ecotoxicity

Marine eutrophication

Freshwater eutrophication

Terrestrial acidification

Ozone formation,

Fine particulate matter..

Ozone formation, Human..

Stratospheric ozone.

Global warming

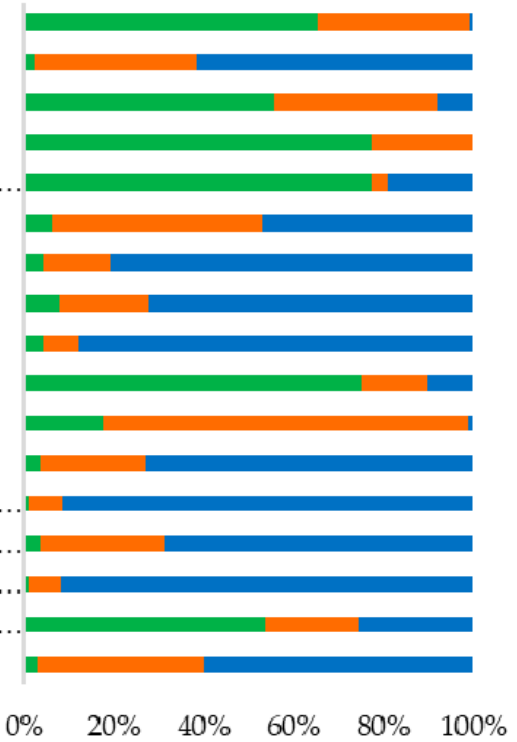

- Para-rubber cultivation, cutting and processing

Wood pellet production (F3)

- Transportation
- Transportation

\section{Case F}
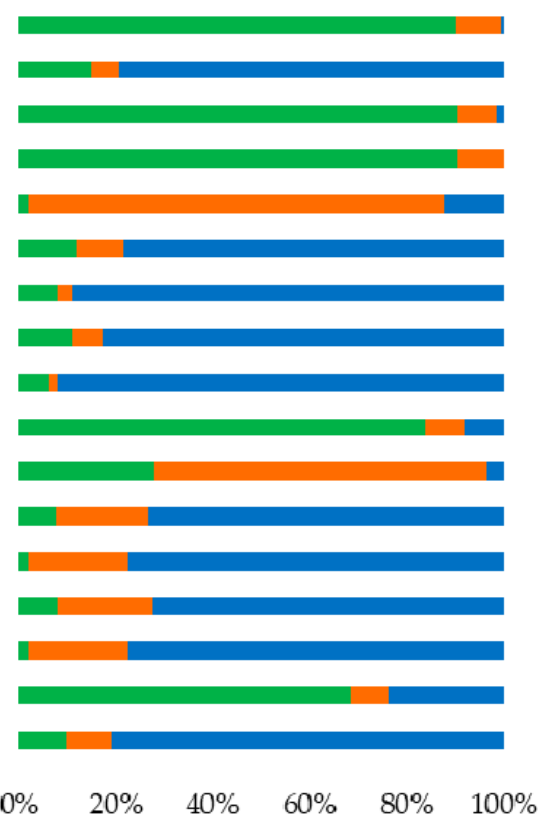

\section{Case $\mathrm{H}$}

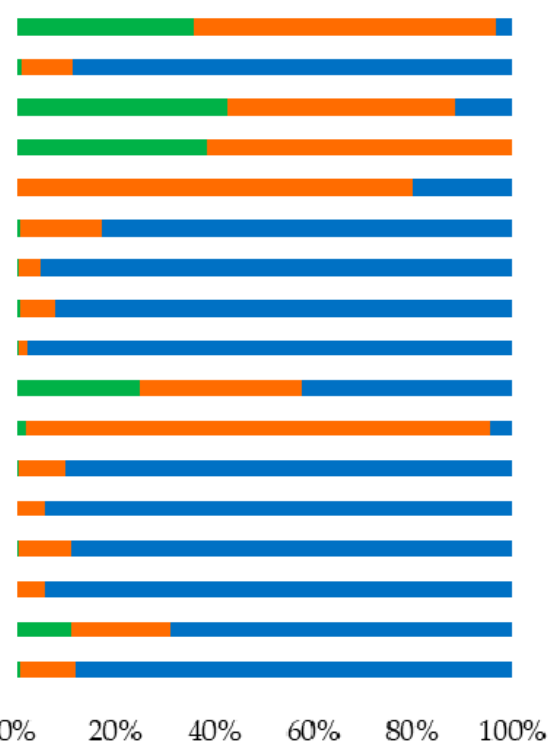

- Para-rubber cultivation, cutting and processing - Wood pellet production (F4)

- Transportation

Figure 6. Contribution of para-rubber tree wood pellets life cycle phases to the midpoint impact categories (Case E-H).

\subsection{Comparing LCA of Electricity Production from Wood Pellets and Fossil Fuels}

The endpoint environmental impacts for electricity production from acacia wood pellets, leucaena wood pellets, and para-rubber wood pellets, lignite, and natural gas (in conventional power plants) 
have been compared. The results of human health and ecosystem quality show that lignite has the highest impacts (Figure 7). The results of ecosystem quality are similar to human health, except that acacia wood pellets are higher than natural gas in ecosystem quality. This is from the higher use of resources for two crops of Acacia plantation in 10 years, which is more than the other crops. The use of wood pellets for electricity production can reduce the endpoint environmental impacts compared to lignite. Resource scarcity of wood pellets are lower than natural gas, but not lignite which has a very low value. This is because, although the quantity of fossil fuels is decreasing, there is still a lot of lignite available in Asia (4900 million tonnes in 2018), especially in China and Indonesia [45]. Hence, the environmental cost of lignite extraction still is lower than other fossil fuels.

Human health (DALY)

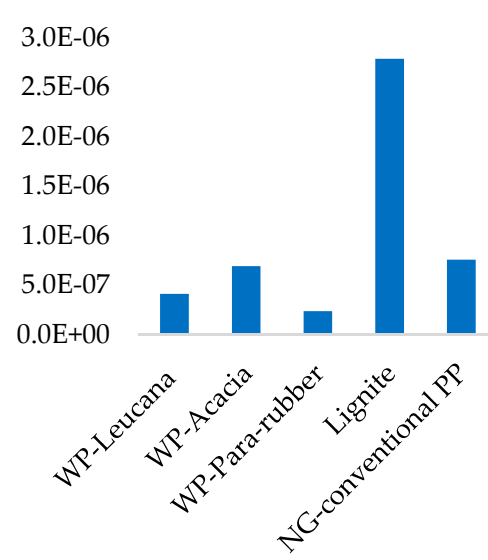

\section{Ecosystem quality} (species.yr)

$7.0 \mathrm{E}-09$
$6.0 \mathrm{E}-09$
$5.0 \mathrm{E}-09$
$4.0 \mathrm{E}-09$
$3.0 \mathrm{E}-09$
$2.0 \mathrm{E}-09$
$1.0 \mathrm{E}-09$
$0.0 \mathrm{E}+00$

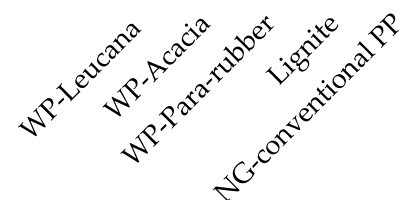

Resource scarcity

(USD2013)

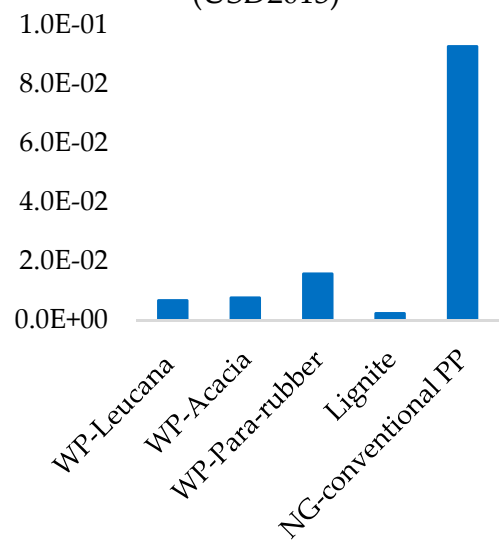

Figure 7. Comparative analysis of wood pellets, lignite, and natural gas endpoint impact profiles for one kWh of electricity production.

Although the environmental burdens of wood pellets are lower than fossil fuels, especially in the dimensions of human health and ecosystem quality, price and availability of raw materials should also be considered for the wood pellet production. Saosee et al. found that the price of raw materials needs to be less than 1300 THB (based on the exchange rate 31.1 THB per US dollar) per tonne for returning a profit [46]. Hence, the cost of fast growing trees and para-rubber wood plantation is an important consideration. From survey results, the cultivation costs of leucaena and acacia are about 13,000 and 12,000 THB per ha, respectively. Their cost is rather close, cost of leucaena plantation is higher due to the requirement for cutting every year. The net present value (NPV) of leucaena and acacia are $9500 \mathrm{THB}$ and $5200 \mathrm{THB}$, respectively (with discount rate $9 \%$, period of time 5 years, leucaena yield: 17 tonnes per ha per year, acacia yield: 88 tonnes per ha per 5 years). Therefore, leucaena is better than acacia, not only from a financial point of view, but also environmental impact assessment results. However, variety of species, cultivar, clone, soil, weather conditions, planting density, agricultural procedures, cultivation, protection measures, and harvest cycle directly affect the yield of short-rotation woody crops [47]. Cultivation cost of para-rubber-tree is 114,000 THB per ha, including cost of latex harvest [48]. However, para-rubber wood is only a byproduct; thus, the raw material of wood pellet production from the para-rubber tree is para-rubber waste wood, which is a waste of a by-product. Hence, the cost of para-rubber plantation is not considered. Moreover, the results present that the kind of wood affects the different impact categories in terms of format of cultivation and yield. The environment burdens of para-rubber waste wood are less than fast growing tree wood.

Considering the ability to procure and distribute raw materials, it was found that there are many para-rubber trees in the southern region. They are available throughout the year except during heavy rains and floods, when cutting of the para-rubber tree reduces. Therefore, wood pellet production in 
the southern region does not have a shortage of raw materials. On the other hand, in the other regions, although raw materials are available in the form of the many types of wood which can be found locally, but their quantity is quite less. Therefore, fast growing trees are expected to have an important role for the wood production in other regions. Although, the wood pellets are still consumed less than woodchips in Thailand, they are a good alternative for electricity and heat production when woodchips are scarce. Du et al. found that the environmental impacts of wood pellets and woodchips are very close, but the wood pellets are a biomass fuel for distributed energy generation, and because they are easier to transport and store, have low moisture content and higher heating value [49].

\subsection{Recommendations}

\subsubsection{Industrial Forest Management}

Industrial forest management is an important life cycle stage which affects the sustainability of wood pellet production. Observations from this study for industrial forest management comprises of three issues. Firstly, comparing leucaena and acacia wood for wood pellet production reveals that different harvesting cycles and number of crops for an equal yield increases the endpoint environmental impacts: human health and ecosystem quality. Therefore, high yield and short harvest cycle of plants for feedstock material for the wood pellet production are preferable. In this study, leucaena is more appropriate than acacia because it can be harvested every year. Secondly, the chemical fertilizers in the para-rubber tree plantations contributed to eutrophication and mineral resource scarcity. Meanwhile, herbicides (paraquat and glyphosate) are directly toxic to humans and ecosystems. Reducing overuse of fertilizers and herbicides should be conscientiously implemented. Several countries have banned the use of glyphosate and paraquat for cultivation [50]. Several organizations and people in Thailand are also calling for their abolishment. However, the Thai government limits the use and supports the registration and training of farmers who need to use them. The government should plan to stop use of hazardous herbicides in the long term and support research on organic herbicides which are environmentally friendly. Finally, good industrial forest management should be planned in the short term. A forest stewardship certificate is requested by importers of wood pellets; the forest stewardship certificate serves as a guarantee that can be offered by the Forest Stewardship Council (FSC) which is a partnership organization, bringing together environmental, social, and economic interests. The forest stewardship certificate will help to confirm that wood pellets are not produced from natural forest wood and to improve the quality of life of Thai farmers. FSC encourages to reduce the use of chemical pesticides in FSC-certified plantations, including the prevention and mitigation of the related environmental and social impacts.

\subsubsection{Factory Management}

Four issues on factory management can be concluded from the results of this study. Firstly, pollutants from wood pellet production are emissions to air and wood ash from the combustion of drying process, and particulate matter/dust from the production line. Air emissions contribute to ozone formation, stratospheric ozone depletion, and fine particulate matter formation, and wood ash causes eutrophication and human non-carcinogenic toxicity. Thus, equipment and technology for mitigating or removing pollutants before emission to the environment are necessary. From surveying the wood pellet factories, it was found that they used scrubbers, cyclones, and bag filters. They grew a lot of trees around their factories for a buffer zone to reduce noise and dust to the community. However, pollution control must be monitored and rechecked by government agencies. Secondly, (long distance) transportation in Case $\mathrm{H}$ indicates that the environmental impacts of diesel use can be significant. Although the Factory F4 of Case $\mathrm{H}$ still managed to get some profit from selling wood pellets, the use of wood pellets from Case $\mathrm{H}$ will not achieve the goal of users who need to change fuel to reduce the environmental impacts from fossil fuels. The environmental impacts of wood pellet production will be passed on to the users. This problem must be solved by good logistics management. 
Entrepreneurs should raise awareness about the environmental impacts from transportation and wood pellet production. They should find the new raw material sources which are near the factories, leading to lower cost and fuel use. Moreover, return trips should plan to load fully instead of being empty; thus, reducing the cost of transport and environmental impacts. Thirdly, energy management of wood pellet production is significant because it is a major point to reduce the environmental impacts. Energy consumption in wood pellet production of Factory F1 increases all environmental impacts, except land use and water consumption. Hence, initial activity for energy management is energy efficiency. Entrepreneurs should recheck the energy efficiency of equipment and cut unnecessary processes. The wood pellet production consumes energy as heat and electricity. Entrepreneurs should select renewable energy to substitute fossil fuels. Moreover, raw materials with low moisture content support to reduce fuel use in the drying process. Entrepreneurs can consider a method to decrease high moisture content by sunlight, reducing the fuel for drying process. Finally, feedstock access is a factor for sustainability of wood pellet production. Entrepreneurs can plan to grow fast growing trees or support farmers to do it, like contract farming. Possession of raw material supports entrepreneurs to control the quantity of production continuously.

\subsubsection{Government}

Recommendations for the government consist of four issues to encourage the stakeholders (farmers, entrepreneurs, and users) towards the sustainability of wood pellet production. Firstly, the government should increase awareness of the stakeholders about the environmental impacts from the processes of wood pellet production, including advantages and disadvantages of wood pellet use, and safety in production and use. Secondly, to create strategies and incentives like tax reduction for the wood pellet factories or users who can reduce $\mathrm{CO}_{2}$. To support fund for farmers who can show the forest stewardship certificates, and wood pellet users to adapt incinerators for wood pellet combustion. These strategies should be created by the involvement of the stakeholders and the Thai government to facilitate implementation. Thirdly, to consider the externality cost for wood pellet production to reflect the actual cost of pollution reduction. The externality cost consideration can be the plan for long term. Finally, the government should support new technology to produce wood pellets, for example, reducing moisture content of raw materials by equipment consuming low energy and development of torrefied wood pellet production under low cost conditions.

\section{Conclusions}

The endpoint impact assessment results of wood pellet production show that leucaena is better than acacia due to short harvest cycle and use of less resources in a crop. The use of diesel in vehicles for long distance transport to collect raw material increases all endpoint environmental impacts. Although the endpoint environmental impacts of using trunks of para-rubber-tree were low, some midpoint impacts such as stratospheric ozone depletion, marine eutrophication, land use, and mineral resource scarcity were the highest as compared with the other cases. The wood pellet production process still uses fossil fuels (diesel for transportation or electricity from coal for activity in factories), which is an important cause of environmental impacts. Although energy derived from wood pellets is considered renewable, industrial forest plantations also use chemical fertilizers and herbicides which affect ecosystem and human health. In addition, the format of planting and harvesting of plants also affects differently the environmental impacts and use of resources in the case of leucaena and acacia. Recommendations from this study focus on increasing yield of raw material plants, shortening harvesting cycle, reducing overuse of fertilizers and herbicides, supporting the application for forest certificate, pollution control, reducing fossil fuel use, good logistics, and feedstock possession. Moreover, the Thai government should communicate with stakeholders about knowledge and awareness of mitigation of the environmental impacts, and provide incentives, considering the externality cost and supporting related research. 
Author Contributions: Conceptualization, P.S., S.H.G., and B.S.; methodology, P.S.; validation, P.S.; writingoriginal draft preparation, P.S.; writing—review and editing, S.H.G.; visualization, B.S.; and supervision, S.H.G. All authors have read and agreed to the published version of the manuscript.

Funding: This research was funded by the Joint Graduate School of Energy and Environment at King Mongkut's University of Technology Thonburi and the Energy Policy and Planning Office, Ministry of Energy, Thailand.

Acknowledgments: The authors would like to thank farmers and staff at the wood pellet factory for kindly providing information.

Conflicts of Interest: The authors declare no conflict of interest.

\section{Appendix A}

Table A1. Economic allocation of products from one para-rubber tree.

\begin{tabular}{ccccc}
\hline Product & $\begin{array}{c}\text { Quantity (1) } \\
\mathbf{( k g )}\end{array}$ & $\begin{array}{c}\text { Price (2) } \\
\text { (THB/kg) }\end{array}$ & (1) $\times(\mathbf{2})$ & $\begin{array}{c}\text { Economic } \\
\text { Allocation (\%) }\end{array}$ \\
\hline Plantation & & & & \\
Fresh rubber wood & 592.21 & $2.40^{*}$ & 1421.30 & 31.10 \\
Latex & 70.51 & $44.66^{* *}$ & 3148.82 & 68.90 \\
Cutting & Total & 4570.12 & 100.00 \\
Rubber wood Log & 445.11 & $2.40^{* *}$ & 1068.26 & 94.79 \\
Branch & 146.89 & $0.40^{* *}$ & 58.76 & 5.21 \\
& & Total & 1127.02 & 100.00 \\
Sawing \& Processing & & & & \\
Kiln-dried rubber wood & 222.56 & $20.50^{*}$ & 4562.38 & 97.43 \\
Bark & 178.04 & $0.50^{* * *}$ & 89.02 & 1.90 \\
Fresh sawdust & 44.51 & $0.70^{* * *}$ & 31.16 & 0.67 \\
& & Total & 4682.56 & 100.00 \\
Jointed board rubberwood & 156.58 & $30.22^{* * *}$ & 4731.95 & 99.03 \\
Dry sawdust & 65.97 & $0.70^{* * *}$ & 46.18 & 0.97 \\
Plywood & & Total & 4778.13 & 100.00 \\
Dry sawdust & 133.62 & $41.64^{* * *}$ & 5563.80 & 99.71 \\
& 22.97 & $0.70^{* * *}$ & 16.08 & 0.29 \\
& & Total & 5579.87 & 100.00
\end{tabular}

* Thai Hevea Wood Associate, 2018. ** Rubber Authority of Thailand, 2018. ** Rubber wood processing enterprises, 2019. Average price of para-rubber wood is $2.14 \pm 0.32 \mathrm{THB}$ per $\mathrm{kg}$ (2016-2019). In this study, the price of para-rubber wood is chosen at 2.4 THB per $\mathrm{kg}$ to consider the maximum of environmental burdens.

\section{Appendix B}

Table A2. Life cycle inventory data for para-rubber tree cultivation and sawmill operation [31].

\begin{tabular}{ccc}
\hline Process/Activity & Unit & Amount \\
\hline $\begin{array}{c}\text { Cultivation } \\
\text { 1. Sprout preparation } \\
\text { Input }\end{array}$ & & \\
Fresh seed & & \\
Black bag & $\mathrm{kg}$ & $7.10 \times 10^{-3}$ \\
Soil & $\mathrm{kg}$ & $7.04 \times 10^{-3}$ \\
Tape & $\mathrm{kg}$ & 2.04 \\
$\mathbf{M a n c o z e b}^{\text {Fosetyl-aluminum }}$ & $\mathrm{kg}$ & $4.76 \times 10^{-4}$ \\
Water & $\mathrm{kg}$ & $4.95 \times 10^{-5}$ \\
Fertilizer & $\mathrm{kg}$ & $4.02 \times 10^{-5}$ \\
$\mathbf{N}$ & $\mathrm{m}$ & $1.06 \times 10^{-2}$ \\
$\mathbf{P}_{\mathbf{2}} \mathbf{O}_{\mathbf{5}}$ & $\mathrm{kg}$ & \\
$\mathbf{K}_{\mathbf{2}} \mathbf{O}$ & $\mathrm{kg}$ & $5.17 \times 10^{-4}$ \\
$\mathbf{D i e s e l}^{3}$ & $\mathrm{~kg}$ & $1.58 \times 10^{-4}$ \\
$\mathrm{~kg}$ & $2.03 \times 10^{-4}$ \\
& $\mathrm{~L}$ & $1.86 \times 10^{-3}$ \\
\hline
\end{tabular}


Table A2. Cont.

\begin{tabular}{|c|c|c|}
\hline Process/Activity & Unit & Amount \\
\hline Gasoline & $\mathrm{L}$ & $2.77 \times 10^{-3}$ \\
\hline Electricity & unit & $2.81 \times 10^{-4}$ \\
\hline Output of para-rubber sprout & bag & 1 \\
\hline \multicolumn{3}{|l|}{ 2. Para-rubber tree plantation (per $0.16 \mathrm{ha}$ ) } \\
\hline \multicolumn{3}{|l|}{ Input } \\
\hline Rubber tree & bag & 77.00 \\
\hline Paraquat & $\mathrm{kg}$ & 12.10 \\
\hline Glyphosate & $\mathrm{kg}$ & 5.04 \\
\hline Water & $\mathrm{m}^{3}$ & 1445.64 \\
\hline \multicolumn{3}{|l|}{ Fertilizer } \\
\hline $\mathbf{N}$ & $\mathrm{kg}$ & 380.17 \\
\hline $\mathrm{P}_{2} \mathrm{O}_{5}$ & $\mathrm{~kg}$ & 189.83 \\
\hline $\mathrm{K}_{2} \mathrm{O}$ & $\mathrm{kg}$ & 303.83 \\
\hline Diesel & $\mathrm{L}$ & \\
\hline Gasoline & $\mathrm{L}$ & 31.83 \\
\hline \multicolumn{3}{|l|}{ Output of para-rubber tree plantation } \\
\hline Latex & $\mathrm{kg}$ & 5429 \\
\hline Para-rubber tree (excluding root) & $\mathrm{kg}$ & 45,600 \\
\hline \multicolumn{3}{|l|}{ 3. Para-rubber tree cutting } \\
\hline \multicolumn{3}{|l|}{ Input } \\
\hline Fresh rubber wood (not include root) & $\mathrm{kg}$ & 1.33 \\
\hline Gasoline & $\mathrm{L}$ & $5.42 \times 10^{-4}$ \\
\hline Lubricant oil & $\mathrm{L}$ & $2.43 \times 10^{-4}$ \\
\hline Diesel (transportation in a farm) & $\mathrm{L}$ & 0.0016 \\
\hline \multicolumn{3}{|l|}{ Output of para-rubber tree cuttings } \\
\hline Para-rubber wood log & $\mathrm{kg}$ & 1 \\
\hline Branches & $\mathrm{kg}$ & 0.33 \\
\hline
\end{tabular}

Table A3. Life cycle inventory data for para-rubber wood processing [32].

\begin{tabular}{ccc}
\hline Process/Activity & Unit & Amount \\
\hline 1. Kiln-dried para-rubber wood processing & & \\
Input & & \\
Para-rubber wood log & $\mathrm{kg} /$ year & $111,462,066$ \\
Saw blade & $\mathrm{kg} /$ year & 3672 \\
Boron & $\mathrm{kg} /$ year & 66,541 \\
Calcium hypochlorite & $\mathrm{kg} /$ year & 6225 \\
Electricity & $\mathrm{kWh} / \mathrm{year}$ & $1,475,756$ \\
Diesel (saw) & $\mathrm{kg} /$ year & 4553 \\
Waste wood & $\mathrm{kg} /$ year & $15,600,745$ \\
Sawdust & $\mathrm{kg} /$ year & $4,179,425$ \\
Water & $\mathrm{kg} /$ year & $9,115,301$ \\
Output of kiln-dried para-rubber wood processing & $\mathrm{kg} /$ year & 55,731 \\
Kiln-dried para-rubber wood & $\mathrm{kg} /$ year & 44,585 \\
Bark & $\mathrm{kg} /$ year & 11,146 \\
Sawdust & $\mathrm{kg} /$ year & 1681 \\
Ash & & \\
Input & & \\
2. Jointed board para-rubber wood processing & $\mathrm{kg} /$ year & $5,774,105$ \\
Kiln-dried para-rubber wood & $\mathrm{kg} /$ year & 49 \\
Lubricant oil & $\mathrm{kg} /$ year & 47,922 \\
Polyvinyl acetate (PVAc) & $\mathrm{kWh} /$ year & $1,211,221$ \\
Electricity & & \\
Output & $\mathrm{kg} /$ year & $4,110,211$ \\
Sawdust & $\mathrm{kg} /$ year & $1,663,894$ \\
\hline Jointed board para-rubber wood & &
\end{tabular}


Table A3. Cont.

\begin{tabular}{ccc}
\hline Process/Activity & Unit & Amount \\
\hline 3. Plywood processing & & \\
Input & & \\
Jointed board para-rubber wood & $\mathrm{kg} /$ year & $4,133,202$ \\
Polyethylene plastic & $\mathrm{kg} /$ year & 4012 \\
Lubricant oil & $\mathrm{kg} /$ year & 120 \\
Electricity & $\mathrm{kWh} /$ year & 801,463 \\
Diesel & $\mathrm{kg} /$ year & 2028 \\
Output & & \\
Plywood & $\mathrm{kg} /$ year & $3,564,633$ \\
Sawdust & $\mathrm{kg} /$ year & 568,569 \\
\hline
\end{tabular}

\section{Appendix C}

Table A4. Life cycle inventory data for Leucaena and Acacia cultivation.

\begin{tabular}{|c|c|c|c|}
\hline Process/Activity & Unit & Leucaena & Acacia \\
\hline \multicolumn{4}{|l|}{ Cultivation } \\
\hline \multicolumn{4}{|c|}{ 1. Sprout preparation ${ }^{1}$} \\
\hline \multicolumn{4}{|l|}{ Input } \\
\hline Fresh seed & $\mathrm{kg}$ & 0.000016 & 0.000018 \\
\hline Black bag $2 \times 6$ inch $^{2}$ & $\mathrm{~kg}$ & 0.0025 & 0.0025 \\
\hline Soil & $\mathrm{kg}$ & 0.13 & 0.13 \\
\hline Water & $\mathrm{m}^{3}$ & 3.0 & 3.0 \\
\hline Manure (chicken) & $\mathrm{kg}$ & 0.00042 & 0.00042 \\
\hline Gasoline & $\mathrm{L}$ & 0.000088 & 0.000088 \\
\hline Electricity & kWh & 0.0069 & 0.0069 \\
\hline Output of plant sprout & bag & 1 & 1 \\
\hline \multicolumn{4}{|c|}{ 2. Plantation and cutting (per 0.16 ha) [44] } \\
\hline \multicolumn{4}{|c|}{ Input } \\
\hline Time to grow & year & 10 & 5 \\
\hline Sprout & bag & 800 & 800 \\
\hline Diesel (for sowing) & $\mathrm{L}$ & 12.0 & 12.0 \\
\hline Chemical fertilizer (15-15-15) & $\mathrm{kg}$ & 50.0 & 25.0 \\
\hline Electricity (for cutting) & $\mathrm{kWh}$ & 358 & 182 \\
\hline Output of plantation and cutting 2 & $\mathrm{~kg}$ & 27.05 & 13.76 \\
\hline
\end{tabular}

\footnotetext{
${ }^{1}$ Source: primary data collected from a farm in Uthaithani province. ${ }^{2}$ Average value at rainfall $1200-1500 \mathrm{~mm}$ per year and planting spec $1 \times 2 \mathrm{~m}^{2}$; Yield of Leucaena $=2.705$ tonne per 0.16 ha per year (dry weight); Yield of Acacia $=2.751$ tonne per 0.16 ha per year (dry weight).
}

\section{Appendix D}

Table A5. Air emission from combustion of one tonne dry wood residue (Firewood).

\begin{tabular}{ccc}
\hline Emission to Air & Unit & Amount \\
\hline Particulates, unspecified & $\mathrm{kg}$ & 0.725 \\
Particulates, $<10 \mu \mathrm{m}$ & $\mathrm{kg}$ & 0.537 \\
Particulates, $<2.5 \mu \mathrm{m}$ & $\mathrm{kg}$ & 0.471 \\
Nitrogen oxides & $\mathrm{kg}$ & 3.554 \\
Sulfur dioxide & $\mathrm{kg}$ & 0.181 \\
Carbon monoxide, biogenic & $\mathrm{kg}$ & 4.352 \\
Hydrogen chloride & $\mathrm{kg}$ & 0.138 \\
Methane, biogenic & $\mathrm{kg}$ & 0.152 \\
Organic substances, unspecified & $\mathrm{kg}$ & 0.283 \\
VOC, volatile organic compounds & $\mathrm{kg}$ & 0.123 \\
Dinitrogen monoxide & $\mathrm{kg}$ & 0.094 \\
\hline
\end{tabular}

Source: U.S. Life Cycle Inventory Database. 


\section{Appendix E}

Table A6. Air emission of One tonne of wood pellets [51].

\begin{tabular}{ccc}
\hline Air Emission & Unit & Amount \\
\hline $\mathrm{CO}_{2}$-eq & $\mathrm{g}$ & 16 \\
$\mathrm{CO}$ & $\mathrm{g}$ & 18 \\
$\mathrm{NOx}$ & $\mathrm{g}$ & 6 \\
$\mathrm{SO}_{2}$ & $\mathrm{~g}$ & 8 \\
$\mathrm{PM}$ & $\mathrm{g}$ & 3 \\
$\mathrm{PM} 2.5$ & $\mathrm{~g}$ & 3 \\
\hline
\end{tabular}

\section{References}

1. Jåstad, E.O.; Bolkesjø, T.F.; Trømborg, E.; Rørstad, P.K. The role of woody biomass for reduction of fossil GHG emissions in the future North European energy sector. Appl. Energy 2020, 274, 115360. [CrossRef]

2. Jackson, R.W.; Neto, A.B.F.; Erfanian, E. Woody biomass processing: Potential economic impacts on rural regions. Energy Policy 2018, 115, 66-77. [CrossRef]

3. Pan, S.-Y.; Lin, Y.J.; Snyder, S.W.; Ma, H.-W.; Chiang, P.-C. Development of Low-Carbon-Driven Bio-product Technology Using Lignocellulosic Substrates from Agriculture: Challenges and Perspectives. Curr. Sustain. Energy Rep. 2015, 2, 145-154. [CrossRef]

4. Thrän, D.; Peetz, D.; Schaubach, K. Global Wood Pellet Industry and Trade Study 2017; IEA Bioenergy: Brussels, Belgium, 2017; ISBN 9781910154328.

5. Sun, L.; Niquidet, K. Elasticity of import demand for wood pellets by the European Union. For. Policy Econ. 2017, 81, 83-87. [CrossRef]

6. Boukherroub, T.; LeBel, L.; Lemieux, S. An integrated wood pellet supply chain development: Selecting among feedstock sources and a range of operating scales. Appl. Energy 2017, 198, 385-400. [CrossRef]

7. European Pellet Council World Pellet Map. Available online: https://epc.bioenergyeurope.org/about-pellets/ pellets-statistics/world-pellet-map/ (accessed on 20 January 2020).

8. Thrän, D.; Schaubach, K.; Peetz, D.; Junginger, M.; Mai-Moulin, T.; Schipfer, F.; Olsson, O.; Lamers, P. The dynamics of the global wood pellet markets and trade-Key regions, developments and impact factors. Biofuels Bioprod. Biorefin. 2018. [CrossRef]

9. Jonsson, R.; Rinaldi, F. The impact on global wood-product markets of increasing consumption of wood pellets within the European Union. Energy 2017, 133, 864-878. [CrossRef]

10. Kasikorn Research Center Market. Opportunity of Wood Pellet in Thailand. Available online: https: //kasikornresearch.com/th (accessed on 25 March 2019).

11. Kotrba, R. Asian Wood Pellet Producer Market Snapshot. Available online: http://biomassmagazine.com/ articles/13880/asian-wood-pellet-producer-market-snapshot (accessed on 15 March 2019).

12. International Renewable Energy Agency. Renewable Energy Outlook: Thailand; International Renewable Energy Agency: Masdar, UAE, 2017; ISBN 9789292600358.

13. Department of Alternative Energy, Development and Efficiency; King Mongkut's Institute of Technology Ladkrabang. Using Wood Pellet for Small Boiler in Industry, Bangkok; Department of Alternative Energy, Department and Efficiency: Bangkok, Thailand, 2016.

14. Haruthaithanasan, M. The Potential of Degraded Land for Fast Growing Tree Plantation for Power Generation; Thailand Science Research and Innovation: Bangkok, Thailand, 2014.

15. Tudsri, S.; Sripijit, P.; Wongsuwan, N.; Nakmanee, K. Leucaena Biomass Production for Sustainable Renewable Energy; National Research Council of Thailand: Bangkok, Thailand, 2009.

16. Kasetsart University; Royal Forest Department. Development of Acacia Genus Planting on Degraded Land for Power Generation; Food and Agriculture Organization of the United Nations Regional Office for Asia and the Pacific: Bangkok, Thailand, 2011.

17. Hossain, M.U.; Leu, S.-Y.; Poon, C.S. Sustainability analysis of pelletized bio-fuel derived from recycled wood product wastes in Hong Kong. J. Clean. Prod. 2016, 113, 400-410. [CrossRef]

18. ISO 14040:2006. Environmental Management_Life Cycle Assessment_Principles and Framework; International Organization for Standardization: Geneva, Switzerland, 2006. 
19. Rebitzer, G.; Ekvall, T.; Frischknecht, R.; Hunkeler, D.; Norris, G.; Rydberg, T.; Schmidt, W.-P.; Suh, S.; Weidema, B.P.; Pennington, D.W. Life cycle assessment: Part 1: Framework, goal and scope definition, inventory analysis, and applications. Environ. Int. 2004, 30, 701-720. [CrossRef]

20. Kylili, A.; Christoforou, E.; Fokaides, P.A. Environmental evaluation of biomass pelleting using life cycle assessment. Biomass Bioenergy 2016, 84, 107-117. [CrossRef]

21. Laschi, A.; Marchi, E.; González-García, S. Environmental performance of wood pellets' production through life cycle analysis. Energy 2016, 103, 469-480. [CrossRef]

22. Muazu, R.I.; Borrion, A.L.; Stegemann, J.A. Life cycle assessment of biomass densification systems. Biomass Bioenergy 2017, 107, 384-397. [CrossRef]

23. Rajabi Hamedani, S.; Colantoni, A.; Gallucci, F.; Salerno, M.; Silvestri, C.; Villarini, M. Comparative energy and environmental analysis of agro-pellet production from orchard woody biomass. Biomass Bioenergy 2019, 129, 105334. [CrossRef]

24. Saosee, P.; Sajjakulnukit, B.; Gheewala, S.H. Life cycle assessment of wood pellet from para-rubber tree residues. In Proceedings of the 18th International Conference on Sustainable Energy Technologies (SET 2019), Kuala Lumpur, Malaysia, 20-22 August 2019; p. 552.

25. De la Fuente, T.; Bergström, D.; González-García, S.; Larsson, S.H. Life cycle assessment of decentralized mobile production systems for pelletizing logging residues under Nordic conditions. J. Clean. Prod. 2018, 201, 830-841. [CrossRef]

26. Quinteiro, P.; Tarelho, L.; Marques, P.; Martín-Gamboa, M.; Freire, F.; Arroja, L.; Dias, A.C. Life cycle assessment of wood pellets and wood split logs for residential heating. Sci. Total Environ. 2019. [CrossRef]

27. Ruiz, D.; San Miguel, G.; Corona, B.; López, F.R. LCA of a multifunctional bioenergy chain based on pellet production. Fuel 2018, 215, 601-611. [CrossRef]

28. Dias, G.M.; Ayer, N.W.; Kariyapperuma, K.; Thevathasan, N.; Gordon, A.; Sidders, D.; Johannesson, G.H. Life cycle assessment of thermal energy production from short-rotation willow biomass in Southern Ontario, Canada. Appl. Energy 2017, 204, 343-352. [CrossRef]

29. Adams, P.W.R.; Shirley, J.E.J.; McManus, M.C. Comparative cradle-to-gate life cycle assessment of wood pellet production with torrefaction. Appl. Energy 2015, 138, 367-380. [CrossRef]

30. Huijbregts, M.A.J.; Steinmann, Z.J.N.; Elshout, P.M.F.; Stam, G.; Verones, F.; Vieira, M.; Zijp, M.; Hollander, A.; van Zelm, R. ReCiPe2016: A harmonised life cycle impact assessment method at midpoint and endpoint level. Int. J. Life Cycle Assess. 2017, 22, 138-147. [CrossRef]

31. Musikavong, C.; Hanpongkittikun, A.; Sdoodee, S.; Suksaroj, C.; Jungcharoentham, N. Assessment Water Footprint in the Rubber Plantations in the New Area of the South of Thailand; Thailand Science Research and Innovation: Bangkok, Thailand, 2015.

32. Phungrassami, H.; Usubharatana, P. Life cycle assessment and eco-efficiency of para-rubber production in Thailand. Pol. J. Environ. Stud. 2015, 24, 2113-2126.

33. Chotchutima, S.; Tudsri, S.; Kangvansaichol, K.; Sripichitt, P. Effects of sulfur and phosphorus application on the growth, biomass yield and fuel properties of leucaena (Leucaena leucocephala (Lam.) de Wit.) as bioenergy crop on sandy infertile soil. Agric. Nat. Resour. 2016, 50, 54-59. [CrossRef]

34. Ter-Mikaelian, M.; Colombo, S.J.; Chen, J. The burning question: Does forest bioenergy reduce carbon emissions? A review of common misconceptions about forest carbon accounting. J. For. 2015, 113, 57-68. [CrossRef]

35. Khaenson, W.; Maneewan, S.; Punlek, C. Life Cycle Assessment of Power Generation from Renewable Energy in Thailand. GMSARN Int. J. 2016, 10, 145-156. [CrossRef]

36. Kato, S.; Maruyama, N.; Nishimura, A.; Widiyanto, A.; Sampattagul, S. LCA/LCC of Mae Moh Coal-fired Power Plant in Thailand, Proceedings of the Environmental Engineering Symposium, 2003; The Japan Society of Mechanical Engineers: Tokyo, Japan, 20-23 April 2003; Volume 2003, pp. 402-405.

37. Usapein, P.; Chavalparit, O. Life Cycle Assessment of Producing Electricity in Thailand: A Case Study of Natural Gas Power Plant. In Proceedings of the MATEC Web of Conferences, Hong Kong, China, 1-3 July 2017; Volume 103.

38. Bonan, G. Ecological Climatology: Concepts and Applications; Cambridge University Press: New York, NY, USA, 2016; ISBN 978-1-107-04377-0. 
39. Proto, A.R.; Bacenetti, J.; Macrì, G.; Zimbalatti, G. Roundwood and bioenergy production from forestry: Environmental impact assessment considering different logging systems. J. Clean. Prod. 2017, 165, 1485-1498. [CrossRef]

40. Bacenetti, J. Heat and cold production for winemaking using pruning residues: Environmental impact assessment. Appl. Energy 2019, 252, 113464. [CrossRef]

41. Intergovernmental Panel on Climate Change Climate Change and Land. Available online: https://www.ipcc. ch/site/assets/uploads/2019/08/4.-SPM_Approved_Microsite_FINAL.pdf (accessed on 15 July 2020).

42. Chiarawipa, R.; Pechkeo, S.; Prommee, M.; Wittaya, K. Assessment of Carbon Stock and the Potential Income of the Carbon Offset in Rubber Plantation. Burapha Sci. 2012, 17, 91-102.

43. Bridhikitti, A. Soil and biomass carbon stocks in forest and agricultural lands in tropical climates. Songklanakarin J. Sci. Technol 2017, 39, 697-707.

44. Arjharn, W. Greenhouse Gas Inventory Development for Fast-Growing Trees Used as Biomass Fuel in Thailand; National Research Council of Thailand: Korat, Thailand, 2014.

45. Enerdata Growing Economy \& Access to Electricity Mean Booming Energy Use in Southeast Asia. Available online: https://www.enerdata.net/publications/executive-briefing/growing-economy-accesselectricity-mean-booming-energy-use-southeast-asia.html (accessed on 15 July 2020).

46. Saosee, P.; Sajjakulnukit, B.; Gheewala, S.H. Environmental and Socio-economic Assessment of Wood pellet Production from Fast growing trees in Thailand. In Proceedings of the International Conference on Sustainable Energy and Green Technology, Bangkok, Thailand, 11-14 December 2019.

47. Stolarski, M.J.; Krzyżaniak, M. Short-Rotation Woody Crops for Energy; Elsevier: Amsterdam, The Netherlands, 2017; ISBN 9780128047927.

48. Office of Agricultural Economics. Agricultural Economic Information. Available online: http://www.oae.go.th/view/1/\%E0\%B8\%A2\%E0\%B8\%B2\%E0\%B8\%87\%E0\%B8\%9E\%E0\%B8\%B2\% E0\%B8\%A3\%E0\%B8\%B2/TH-TH (accessed on 15 May 2019).

49. Pereira, M.F.; Nicolau, V.P.; Bazzo, E. Exergoenvironmental analysis concerning the wood chips and wood pellets production chains. Biomass Bioenergy 2018, 119, 253-262. [CrossRef]

50. Sustainable Pulse Glyphosate Herbicides Now Banned or Restricted in 18 Countries Worldwide. Available online: https://sustainablepulse.com/2019/05/28/glyphosate-herbicides-now-banned-or-restricted-in-17countries-worldwide-sustainable-pulse-research/\#.XZIfxUYza00 (accessed on 28 May 2019).

51. Wang, C.; Chang, Y.; Zhang, L.; Pang, M.; Hao, Y. A life-cycle comparison of the energy, environmental and economic impacts of coal versus wood pellets for generating heat in China. Energy 2017, 120, 374-384. [CrossRef]

(C) 2020 by the authors. Licensee MDPI, Basel, Switzerland. This article is an open access article distributed under the terms and conditions of the Creative Commons Attribution (CC BY) license (http://creativecommons.org/licenses/by/4.0/). 